\title{
Sindromul nefrotic infantil - provocări de diagnostic şi management
}

\author{
Cornel Aldea ${ }^{1}$, Teodora Munteanu', Dan Delean', Bogdan Bulată', Adriana Bungardi', \\ Sorin Man², Mihai Gafencü ${ }^{3}$, Carmen Duicu ${ }^{4}$ \\ ${ }^{1}$ Clinica Pediatrie II, Compartimentul de Nefrologie Pediatrică şi Dializă, SCUC, Cluj-Napoca, România \\ ${ }^{2}$ Clinica Pediatrie III, Universitatea de Medicină şi Farmacie „Iuliu Haţieganu“, \\ SCUC, Cluj-Napoca, România \\ ${ }^{3}$ SCUC „Louis Jurcanu“, Universitatea de Medicină şi Farmacie „Victor Babeş“, Timişoara, România \\ ${ }^{4}$ Clinica Pediatrie I, Universitatea de Medicină şi Farmacie, Tîrgu Mureş, România
}

\begin{abstract}
REZUMAT
Sindromul nefrotic infantil este caracterizat de proteinurie $\left(>40 \mathrm{mg} / \mathrm{m}^{2}\right)$, hipoalbuminemie $(2,5 \mathrm{mg} / \mathrm{dl})$ și edeme cu debut între 4 şi 12 luni. Copiii cu sindrom nefrotic infantil nu prezintă simptomatologie la naștere, proteinuria apare ulterior, este tipic mai puţin severă decât în sindromul nefrotic de tip finlandez şi crește progresiv în primul sau al doilea an. Din punctul de vedere al etiologiei, sindromul nefrotic poate fi idiopatic, genetic sau secundar. Examenul histopatologic nu mai este considerat criteriu cheie în diagnosticul şi prognosticul sindromului nefrotic corticorezistent la copii, având valoare limitatã în delimitarea formelor genetice de alte etiologii. Podocitopatiile genetice au schimbat modul de abordare al diagnosticului, tratamentului şi prognosticului copiilor cu debut precoce al sindromului nefrotic corticorezistent. Deciziile terapeutice sunt luate în funcţie de etiologie.
\end{abstract}

Cuvinte cheie: sindrom nefrotic infantil, determinism genetic, podocitopatii genetice

\section{INTRODUCERE}

Sindromul nefrotic infantil este caracterizat de proteinurie $\left(>40 \mathrm{mg} / \mathrm{m}^{2}\right)$, hipoalbuminemie $(2,5$ $\mathrm{mg} / \mathrm{dl}$ ) şi edeme cu debut între 4 şi 12 luni. Majoritatea cazurilor cu debut la această vârstă au un determinism genetic al afectării renale şi prognostic rezervat.

Sindromul nefrotic cu debut după vârsta de 1 an este denumit sindrom nefrotic al copilului, iar cel cu debut precoce, este considerat congenital în primele 3 luni (1).

Din punctul de vedere al etiologiei, sindromul nefrotic poate fi idiopatic, genetic sau secundar (cauze autoimune, toxice, medicamentoase sau infecțioase).

Conform datelor din registrul internațional de boli renale rare (PodoNet), care cuprinde 1.665 de pacienți a 67 de centre din 21 de țări, Trautmann et al. au identificat debutul sindromului nefrotic corticorezistent în primii 5 ani de viață la $67 \%$ din totalul pacienților. Dintre aceştia, 7\% au fost încadrați ca sindrom nefrotic infantil cu debut precoce (17).

\section{FIZIOPATOLOGIE ŞI GENETICĂ}

Registrul PodoNet a identificat o relație de inversă proporționalitate între determinismul genetic şi vârsta de debut, incidența mutaţiilor patologice scăzând de la 69,4\% în sindromul nefrotic congenital şi 49,7\% în cel infantil la numai $15-16 \%$ la şcolari şi adolescenți (17).

În cele mai multe cazuri, proteinuria este determinată de afectarea componentelor barierei de filtrare glomerulară, compusă din endoteliul capilar, membrana bazală şi celulele epiteliale (care prezin- 
tă prelungiri similare unor pseudopode numite podocite) (2). Proteinuria este înalt selectivă la debut, iar hematuria este rar întâlnită ca dovadă a absenței inflamației la nivelul glomerulilor.

Componentele principale ale fantei de filtrare sunt nefrina, codificată de gena $N P H S 1$, şi podocina (o proteină care interacționează cu nefrina), codificată de gena NPHS2.

Clasic, mutațiile care afectează gena NPHS1 determină apariția sindromului nefrotic congenital de tip finlandez (CNF) în primele 3 luni (3), în timp ce mutaţiile genei NPHS2 sunt responsabile de glomeruloscleroza focal segmentară (GSFS), cu debut ulterior.

Până în prezent, au fost identificate aproape 100 de mutații ale genei NPHS1 (4), incidența acestora fiind de aproximativ 98\% în Finlanda şi 39-80\% în afara acestei țări (39\% în Europa) (5).

Mutaţiile heterozigote compuse ale genei NPHS1 sunt responsabile de debutul tardiv al sindromului nefrotic (media de vârsta este 3 ani, între 6 luni şi 8 ani) (6).

Mutații în gena NPHS2 au fost identificate însă la copiii cu sindrom nefrotic congenital, iar mutaţii în gena NPHS1 au fost descrise în câteva cazuri de sindrom nefrotic infantil şi chiar într-un caz cu debut la adult, lărgindu-se astfel spectrul fenotipic al afecțiunilor renale determinate de mutaţiile genei NPHS1 (6).

Mai puțin frecvente, însă responsabile de sindromul nefrotic cu debut precoce (congenital şi infantil), sunt, de asemenea, şi mutaţiile genelor $W T 1$, PLCE1, LAMB2, NPHS2I, TRPC6 sau LMX1B. Mutația genei $W T 1$, genă care codifică un factor de transcripție tumorală (o proteină responsabilă de dezvoltarea rinichilor şi gonadelor), este întâlnită în sindromul Denys-Drash, mutația genei $L A M B 2$ care codifică beta-2laminina (componentă a membranei bazale) este implicată în sindromul Pierson cu scleroză mezangială difuză, mutația genei NPHS3 (PLCE1) care codifică fosfolipaza C epsilon (o proteină de semnal din familia receptorilor cuplaţi cu proteina $G$ ) este întâlnită în sindromul nefrotic cu debut precoce, iar mutaţia genei TRPC6, care codifică un receptor tranzitor al canalului ionic, este incriminată în apariţia GSFS cu debut tardiv (de tip adult), iar mutaţia în gena LAMX1B în sindromul Nail-Patella $(7,8)$.

Până în prezent, 45 de gene cu transmitere autozomal dominantă sau recesivă au fost identificate în sindromul nefrotic corticorezistent şi/sau ereditar. Genele podocitare explică doar $20-30 \%$ dintre cazurile ereditare de sindrom nefrotic. Deşi se corelează cu doar 10-20\% dintre cazurile sporadice, ele explică cazurile familiale şi cele de sindrom nefrotic infantil în proporție de $57 \%$ până la $100 \%$ (9). În afară de nefrină, au fost identificate şi alte proteine podocitare cum ar fi Neph1, Neph2, FAT1, FAT2 şi dendrina. Ele se asociază extracelular şi interacţionează cu proteine adaptoare localizate în citosolul podocitelor: podocina, CD2AP, ZO-1, CASK şi MAGI-1 (10).

MAGI2 interacționează cu nefrina şi reglează dinamica fantelor diafragmatice şi citoscheletul podocitelor. Mutațiile patogene ale guanilatkinazei MAGI2 (MAG, WW şi PDZ domain-containing 2) au fost raportate de Bierzynska et al. într-o cohortă de pacienți cu sindrom nefrotic corticorezistent congenital şi infantil (11).

În sindromul nefrotic cu debut precoce, au fost descrise şi mutaţii ale genelor implicate în biosinteza coenzimei Q10 (COQ2, PDSS2, COQ6, $A D C K 4)$. Toate cazurile în care s-au identificat mutații ale genei $C o Q 2$ au prezentat manifestări în primul an de viață (12).

Examenul histopatologic nu mai este considerat criteriu cheie în diagnosticul şi prognosticul sindromului nefrotic corticorezistent la copii, având valoare limitată $\hat{i}$ delimitarea formelor genetice de alte etiologii. Cele mai întâlnite entităţi histopatologice de afectare glomerulară în lotul PodoNet au fost glomeruloscleroza focală şi segmentară GSFS (56\%), nefropatia cu leziuni minime (21\%) şi glomerulonefrita mezangioproliferativă (12\%) (17).

Asocierile histopatologice cu mutații patologice specifice se limitează la scleroza mezangială difuză pentru nefropatiile asociate mutaţiilor în gene $W T 1$ şi $P L C E 1$ şi dilatările microchistice ale tubilor contorți proximali în sindromul nefrotic infantil de tip finlandez (21).

\section{ASPECTE CLINICE}

Mutaţii ale diferitelor gene precum şi mutaţii diferite ale aceleaşi gene se manifestă cu sindrom nefrotic cu debut la diferite vârste (13). Mutaţiile genelor implicate în sindromul nefrotic se corelează cu variabilitate fenotipică semnificativă. Mutațiile recesive ale NPHS1, NPHS2, LAMB2 şi PLCE1 determină manifestări clinice severe ale sindromului nefrotic cu debut precoce. Sindromul nefrotic cu transmitere autozomal dominantă este rar şi este întâlnit mai ales în formele juvenile şi la adulții cu sindrom nefrotic familial (14).

Copiii cu sindrom nefrotic infantil nu prezintă simptomatologie la naştere, proteinuria apare ulterior, este tipic mai puțin severă decât în sindromul 
nefrotic de tip finlandez şi creşte progresiv în primul sau al doilea an. Debutul este prin sindrom edematos (edeme declive albe, moi, pufoase, cu semnul godeului pozitiv), precedat adesea de o infecție acută de căi respiratorii superioare sau o înțepătură de insectă. Edemele cresc progresiv şi devin manifeste clinic când retenția de fluide depăşeşte $3-5 \%$ din greutatea corporală inițială. Statusul nutriţional şi creşterea ponderală sunt afectate şi pacienții prezintă susceptibilitate crescută pentru infecții bacteriene (peritonită, infecții respiratorii) şi complicații trombo-embolice în funcție de severitatea sindromului nefrotic. Din cauza pierderilor urinare ale proteinelor transportoare ale hormonilor tiroidieni, pacienții asociază frecvent şi hipotiroidism.

Sindromul nefrotic ereditar poate să prezinte manifestări extrarenale. Sindromul Pierson asociază sindrom nefrotic congenital, malformații oculare şi simptome neurologice (hipotonie, retard psihomotor). Tumora Wilm's poate fi prima manifestare clinică a sindromului Denys Drash (caracterizat de triada: afectare renală progresivă, pseudohermafroditism şi tumora Wilm's). Copiii cu mutaţii ale genei $L M X 1 B$ se prezintă cu sindromul unghie-rotulă (Nail-Patella syndrome), mutațiile în gena INF2 sunt întâlnite în boala Charcot-Marie-Tooth, iar gena $M Y H 9$ prezintă mutații patogene în sindromul Sebastian, Epstein, Fechtner şi May-Hegglin (15).

\section{TRATAMENT}

Deciziile terapeutice sunt luate în funcție de etiologie $(17,18)$. Ținta terapeutică este obținerea şi menținerea remisiunii complete pentru reducerea complicațiilor şi prezervarea funcției renale.

Tratamentul conservator include dietă hiperproteică hiposodată, menținerea echilibrului hidroelectrolitic, substituție proteică, vitaminică, administrare de gama-globuline şi hormoni tiroidieni, precum şi profilaxia infecțiilor şi a complicaţiilor trombo-embolice.

Nefrectomia bilaterală trebuie luată în considerare în cursul progresiei sindromului nefrotic înainte de apariția insuficienței renale, pentru a preveni proteinuria masivă responsabilă de rata mare a complicațiilor şi de retardul de creştere important al acestor copii. De asemenea, este importantă la pacienții cu scleroză difuză mezangială din cauza riscului dezvoltării tumorii Wilm's. O posibilă alternativă a nefrectomiei ar putea fi reducerea presiunii glomerulare prin asocierea inhibitorilor enzimei de conversie a angiotensinei cu indometacin, această asociere având rezultate bune în ceea ce priveşte statusul nutriţional şi scăderea proteinuriei inclusiv într-un caz de scleroză mezangială difuză (16).

Studiile au evidențiat rezultate la fel de bune ale inhibitorilor de calcineurină şi rituximabului la pacienții cu sindrom nefrotic corticorezistent (remisie completă a proteinuriei în $40-50 \%$ dintre cazuri), însă pacienții cu mutații monogenice care afectează funcția şi diferențierea podocitelor nu răspund la terapia imunosupresivă (un sfert până la o treime dintre sindroamele nefrotice corticorezistente izolate şi sindromice) $(17,18)$. Un pacient cu sindrom nefrotic corticorezistent $\mathrm{cu}$ o mutație homozigotă $A D C K 4$ a prezentat remisie partială sub tratament substitutiv cu CoQ10 (15-30 mg/kg/zi) sugerând beneficiul ubiquinonei la aceşti copii (14).

Screening-ul pentru mutațiile genei NPHS2 înaintea iniţierii corticoterapiei la primul episod de sindrom nefrotic nu este justificat având în vedere că doar 5\% din totalul sindroamelor nefrotice au un determinism genetic ( $85 \%$ dintre copiii cu sindrom nefrotic idiopatic sunt cortiscosensibili şi doar o treime din sindroamele nefrotice corticorezistente prezintă o mutație genetică patogenă) (19). Ordinea testării genetice este sugerată de probabilitatea implicării genetice, după cum urmează:

- vârsta de debut: screening-ul la copiii mai mari de 3 luni ar trebui să înceapă cu mutațiile genei NPHS2

- prezența anomaliilor extrarenale: în cazul afectării oculare, screening-ul pentru mutațiile $L A M B 2$ şi screening-ul $W T 1$ pentru ambiguitate genitală

- tipul leziunilor histologice - screening-ul $W T 1$ sau $L A M B 2$ pentru scleroza mezangială difuză.

Un diagnostic genetic este clar superior unei clasificări histopatologice din punct de vedere predictiv al răspunsului şi recurenței post-transplant la terapia imunosupresivă intensificată (17).

Unicul tratament curativ în cele mai multe cazuri de sindrom nefrotic infantil cauzat de defecte genetice al proteinelor podocitare rămâne transplantul renal. Recurența post-transplant a fost identificată în 4,5\% dintre cazurile cu determinism genetic ale cohortei PodoNet (17). La majoritatea copiilor cu mutații homozigote ale genei NPHS1 s-a evidențiat absența nefrinei - principala proteină podocitară. În aceste situații, s-a dovedit eficientă asocierea plasmaferezei cu ciclofosfamida şi anticorpii anti-CD20. Câțiva pacienți cu mutații în gena NPHS2 au dezvoltat, de asemenea, proteinurie post-transplant cu un mecanism diferit încă neidentificat, infirmându-se prezența unor anticorpi 
anti-podocină (20). Momentul inițierii terapiei de substituție renală nu influențează supraviețuirea şi creşterea la copiii cu sindrom nefrotic congenital cauzat de mutații în NPHS1 (17).

\section{DISCUŢII}

Podocitopatiile genetice au schimbat modul de abordare al diagnosticului, tratamentului şi prognosticului copiilor cu debut precoce al sindromului nefrotic corticorezistent. Deşi analiza multiplelor gene implicate este costisitoare şi necesită mult timp, identificarea mutațiilor patogene poate ajuta în evitarea efectelor adverse ale corticoterapiei şi ale altor terapii imunosupresive.

Expresia fenotipică a mutațiilor genelor podocitare este mai variată decât s-a presupus inițial.

$\mathrm{O}$ abordare sistematică a pacienților cu sindrom nefrotic ereditar ar putea fi făcută ținând cont de vârsta de debut, modificările histopatologice, prezența malformațiilor extrarenale şi moştenirea genetică familială (15). Deşi majoritatea modificărilor histopatologice în formele genetice de sindrom nefrotic sunt nespecifice, se evidențiază prevalența GSFS cu dificultăți de tratament, prognostic prost şi adeseori progresie spre stadiul final de insuficiență renală.

Dintre cauzele non-genetice, o tot mai mare importanță se acordă posibilității existenței unui mecanism imuno-mediat, cauzat de prezența unui factor circulant încă neidentificat. Rămâne a se descoperi un al treilea (sau chiar a mai multor) mecanism implicat (22).

Un studiu recent a raportat 2 cazuri de sindrom nefrotic infantil cu remisie completă după infecția cu virusul Zyka. Poate fi întâmplător, dar, de asemenea, este posibil ca studiile ulterioare să identifice un efect pe sistemul imun celular (23).

Tratamentele adresate specific celulei țintă - podocitul, sunt la început de drum, dar prezintă implicații promițătoare în viitorul apropiat (22).

\section{Conflictul de interese}

Autorul (autorii) confirmă faptul că acest conținut al articolului nu are un conflict de interese.

Financial support: none declared 